\title{
Review on the Determinants of Agricultural Productivity and Rural Household Income in Ethiopia
}

\author{
Sura Degefu \\ Ethiopian Institute of Agricultural Research
}

\begin{abstract}
Achieving agricultural productivity growth will not be possible without developing and disseminating improved agricultural technologies that can increase productivity to smallholder agriculture farm. It is significantly important to identify the factors that affect agricultural productivity and find the methods of the rural household income improvements. Therefore, the objective of this article is to review and summarize the different factors that affects agricultural productivity and rural household income in Ethiopia based on studies conducted by different scholars so far. Land-labor ratio, use of fertilizer, use of extension service, use of pesticide, manure, number of oxen used and household size are found to be the most significant variables that affect agricultural labor and land productivity. However, drought has statistically significant and has negative effect on both labor and land productivity by the same magnitude. Labor productivity, non-farm income and land productivity are found to be the most determinants of household income. However, number of dependency ratio is significantly and negatively affecting the rural household income. Sex of the household head is the main socio-economic factor for the variation of income among the rural households. The review also concludes that, Labor productivity is the most potent for factor of production and rural household income enhancement. Then increasing land-labor ratio is important for agricultural productivity enhancement and promotion of both farm labor and non-farm income are best focusing to speed up for the enhancement of rural household income.
\end{abstract}

Keywords: labor productivity; land productivity, rural household income

DOI: $10.7176 / \mathrm{JESD} / 11-18-01$

Publication date:September $30^{\text {th }} 2020$

\section{Introduction}

\subsection{Background of the study}

The Ethiopian economy remains dominated by agriculture. In recent years, this traditional sector has accounted for about $68 \%$ of employment and $34 \%$ of GDP, but is making up a decreasing fraction of output over time. More than 79 million people in Ethiopia rely on agriculture for their livelihoods (World Bank, 2018). While the economy has been growing at official rates of about 10\% per year (e.g. between 2003 and 2016 real GDP grew by $7.7 \%$ per year), many people are still poor and food insecure. The poverty rate in 2015 was $26.7 \%$ and Ethiopia still ranks low on the Global Hunger Index (World Bank, 2018). At the same time, it should be noted that there has been a remarkable improvement in poverty levels over the last fifteen years: back in the 1990s, two thirds of the Ethiopian population lived below the global poverty line of USD 1.90 in purchasing power parity (PPP), whereas national poverty lines suggested poverty rates of 46\% in 1995 and 44\% in 1999 (Dercon and Gollin, 2019).

Since the 1990s, agriculture has played and is still playing a central role in the Ethiopian government's policy goals and development strategies. The government's main development plans include the Sustainable Development and Poverty Reduction Plan (SDPRP) 2002-2005, the Plan for Accelerated and Sustained Development to End Poverty (PASDEP) 2005-2010, and the Growth and Transformation Plans (GTP I and GTP II covering 2010-2015 and 2015-2020, respectively). The foundation of all these plans, especially of the SDPRP and PASDEP, was the Agricultural Development Led Industrialization (ADLI) strategy (Ministry of Planning and Economic Development, 1993). The specific development strategies set out in ADLI were: improving agricultural technologies, especially seeds; using modern inputs, including fertilizers and pesticides; expanding irrigation and infrastructure; and expanding rural non-agricultural opportunities and activities. It is widely accepted that Ethiopia's agricultural growth over the past decades has been central to the economic growth of the country. Official numbers indicate that the value of agricultural production in Ethiopia has more than doubled since 2000 (FAO, 2018). Growth has been attributed to expansion of land and labour use, as well as to the increased use of modern inputs and extension services (Cheru et al., 2019). Production of cereals in 2015/16 was recorded to be three times higher than that in 1995/96; over the same period, cultivated area and crop yields increased by $70 \%$ and $86 \%$, respectively (CSA, 2018).

However, use of modern inputs (including knowledge input) and productivity levels remain low, implying that there is potential for further productivity growth. For example, despite rapid growth in the use of fertilizer and improved seeds, current adoption rates remain quite low (Dercon and Gollin, 2019). Also, there is very limited development of irrigation in Ethiopia, although it is believed to contribute strongly to increasing agricultural production. Both Ethiopia's GTP I and GTP II have set clear targets on crop productivity shifts, use of agricultural inputs and water use for agriculture, and several policy interventions have been put in place to achieve these targets. 
It is widely argued that, achieving agricultural productivity growth will not be possible without developing and disseminating improved agricultural technologies that can increase productivity to smallholder agriculture farm. This subsistence agriculture and low level of rural household income is socially and economically could make unstable the rural society. Therefore, it is significantly important to identify the factors that affect agricultural productivity and find the methods of the rural household income improvements. Therefore, the aim of this review is to identify and summarize the different factors that affects agricultural productivity and household income in Ethiopia based on studies conducted by different scholars so far.

\subsection{Objective of the Review}

The main objectives of this review are:

$>$ To identify determinants of agricultural productivity through review of various studies conducted so far on the subject area.

$>$ To review socioeconomic factors that affects income among rural households.

$>$ To summarize and document the different factors that affects agricultural productivity and household income for easy access to information.

\section{The concepts and Theoretical measurements of Agricultural Productivity}

Agricultural productivity is measured as the ratio of agricultural outputs to agricultural inputs. Improvement in the measurement of land productivity has been identified as the highest priority in new research by the Global Strategy, a recent multi-agency initiative endorsed by the United Nations Statistical Commission in February 2010. Yet measuring land productivity is not simple, and measuring productivity becomes even more complicated when inputs besides land are taken into account. A range of measures of partial and total factor productivity exist, with differing theoretical and practical justifications (Fermont \& Benson, 2011).

\subsection{Defining Productivity Measures}

The measures of smallholder agricultural productivity in several ways, all of which are subject to error, bias, and measurement challenges. This review does not provide a comprehensive survey of productivity measures, but rather discusses the factors that affect agricultural productivity and household income.

\section{Yield measurement}

Yield includes several distinct measures of land productivity that consider land the sole input and crop production the sole output. These measures differ in when during the crop production cycle, the numerator (crop production) and denominator (land area) are measured. In terms of crop production weight, biological or gross yield is measured before harvest-related and postharvest loss. Harvested yield is measured after harvest-related losses, but before postharvest loss. Biological yield and harvested yield are often not clearly distinguished - it is sometimes unclear from reports whether and how harvest-related losses are accounted for in yield calculations. Economic yield takes both harvest-related and postharvest losses into account, but is rarely used, though a growing literature on postharvest losses (e.g., rodents), spoilage (e.g., postharvest physiological deterioration in cassava), and contamination (e.g., mycotoxins) underscores the roles of postharvest processing and storage in increasing food available for consumption and securing higher prices (Reynolds et al., 2015).

Land area in yield calculations may be measured at planting (yield by area planted, including all land area planted to a given crop) or at harvest (yield by area harvested, including only plots or sections of plots where harvest occurred). Harvested yield, which denominates crop production harvested by area harvested, is by far the most common yield measure reported in the literature (Fermont \& Benson, 2011).

However, measuring crop area at the time of harvest ignores potential sources of pre harvest crop damage or failure that can reduce harvested area substantially. Smallholder farmers may experience partial or complete area loss between planting and harvesting due to poor germination or damage from pests, flooding, or drought. Additionally, farmers may forego harvesting land because of a lack of labor availability or market opportunities (Kaminski \& Christiaensen, 2014). In cases where area harvested is less than area planted, yield by area harvested measures are likely to overestimate farmer productivity by excluding from analysis the portions of plots with null yield (Anderson, et al, 2015).

Total factor productivity (TFP) captures total crop and livestock output, including intercrops and byproducts for fodder and fuel, and all inputs, including land, labor, seed and agrochemicals, and production technology (Rezek, et al 2011)Livestock activities, which partial factor productivity measures like crop yield do not capture, are important to the welfare of many rural and agricultural populations, so their measurement is important in accurately assessing smallholder wellbeing. A change in total factor productivity may be driven by technical change (introducing new input or output factors) or efficiency change (increasing output without changing factors of production) (Dias Avila \& Evenson, 2010). Total factor productivity measures are considered superior to partial factor measures in the literature (Fuglie \& Schimmelpfennig, 2010; Alston, 2010; Alston \& Pardey, 2014), but 
partial factor productivity measures are used far more often because they are much simpler to measure and calculate.

Net farm income takes an approach based in finance, calculating net income by subtracting total fixed and variable costs from gross income (Simonyan \& Omolehin, 2012; Birthal, et al., 2015; Rada, 2015). Proponents of this method emphasize that the highest-yielding strategy for smallholder farmers (maximizing $\mathrm{kg} / \mathrm{ha}$ ) may not align with the best income-generating strategy per crop (maximizing net kg per dollar spent) or per farm (choice of crops to maximize net income earned per dollar spent). Net farm income is still subject to limitations, as it can be difficult to quantify inputs like labor or land in terms of monetary cost, and even crop value is difficult to estimate when farmers consume most of their production rather than selling it and when market prices vary seasonally (Carletto et al., 2015b).

None of these measures effectively considers long-term costs and benefits, externalities, or risk management in rural economies. For example, farming decisions may have social and environmental consequences (pollution, deforestation, or use of water resources) that affect the broader community. The literature on ecosystem services valuation quantifies some of these costs and benefits, and offers measures that can be used alongside or integrated with a chosen productivity measure. Near-term choices, for example maximizing yields in the short run by drawing down soil nutrients without replenishing them, may limit sustained productivity increases over the long term. Additionally, in order to minimize or mitigate risk, farmers may make choices that maximize neither yield nor farm income. Diversification into non-farm activities to increase income, reduce risk, and smooth consumption across agricultural seasons is a common practice among smallholders, indicating that channels besides productivity growth need to be considered to improve smallholder wellbeing (Davis., et al., 2010).

\section{Error and Bias in Productivity Measurement and Analysis Aggregate-level measures}

Productivity measures are subject to error and bias at the national aggregate level as well as at the plot level. The FAOSTAT database of the Food and Agriculture Organization (FAO) of the United Nations, which compiles national-level production and yield estimates, is the most widely cited source of yield data (Sandefur \& Glassman, 2015). However, the FAO methodology estimates harvested quantity and area based on reports from national ministries of agriculture, and these estimates may be subject to imprecision and inaccuracy as well as political incentives to over- or under-report yield numbers (. The FAO considers only two of the 44 countries in SubSaharan Africa to have high standards for data collection. Many countries, especially the poorest, lack both financial and human resources to collect accurate agricultural data. And in some cases, FAOSTAT yield estimates differ from those published by ministries of agriculture or national statistical agencies themselves. Furthermore, yields achieved by smallholder farmers may vary substantially from national average estimates when using common crop yield measurements (Waddington, et al., 2010), in part due to the sensitivity of averages to outlier data from very large or very small farms. Anderson et al. (2015) demonstrate this with rice yield data from the 2008-2009 Tanzania National Panel Survey (Jerven, 2014; Sandefur \& Glassman, 2015).

\section{Farm- and plot-level measures}

Measuring inputs and outputs on the farm is also subject to inconsistency and bias. Debate exists in the literature over whether farmer-reported estimates of output quantity and land area are more accurate than weights and distances measured by crop researchers or survey enumerators. Area and quantity harvested can prove quite difficult for farmers to estimate, especially for crops such as cassava that are harvested as needed over several months (Fermont \& Benson, 2011). But harvesting and measurement by enumerators or researchers is timeconsuming and costly, requiring multiple visits to the farm between planting and harvest, and is more easily implemented for cereal crops or cash crops than for continuously harvested crops (Carletto et al., 2015b).

In the case of land area, farmers frequently overestimate the area of small plots, underestimate the area of large plots, and round to even units, all of which can distort productivity measures, especially yields, which have a sole-input. Further, in multiple-visit surveys such as the Living Standards Measurement Study - Integrated Surveys on Agriculture (LSMS-ISA), farmers occasionally report irreconcilable plot measures, such as an area harvested larger than the area planted or larger than the farmer-reported plot size, presenting a challenge to analysts. Measurement by GPS or rope and compass is possible for land area, but as with crop production, is time-consuming, costly, and subject to bias. For example, plots that go unmeasured in a survey are systematically different typically farther away from households or roads, and often larger - from those plots that are measured. In the case of some LSMS-ISA data, so many plots in a sample are missing useable measurement data that analysis is impossible or constrained by low statistical power. Measurement error in GPS technology estimates can range from .5 to 4 meters, which is substantial for very small plots. And with any estimation method, accurate measurement is complicated by irregularly shaped plots, obstructions like stumps or anthills, and sloped plots, for which surface area is larger than productive area. Unit conversion adds another layer of complexity to yield measurement. "Heaping" in the data, or clustering around common, even estimates such as one acre for plot area, 
that results from rounding is less apparent to the analyst when measures are converted from one area or weight unit to another (e.g., from 1 acre to .405 hectares) (Fermont \& Benson, 2011).

\section{Productivity Measures Used in Recent Literature}

In peer-reviewed agricultural economics journals, authors use a variety of productivity measures as outcome variables. Yield is the most commonly used, but calculation methods such as whether yield is denominated by area planted or area harvested typically are not specified. Forty-four percent of the 25 articles on agricultural productivity in developing countries published in 2015 used an undefined measure of yield.1 One article specified the use of yield by area planted, four others converted yield to sale value using production value per hectare, and the rest used technical efficiency, total factor productivity, a variety of measures of farm and non-farm income, and other measures including value added per land area and yield treatment effect less cost treatment effect.

\subsection{The concepts and Theoretical Measurements of Rural Household Income}

The decision of rural households to participate in nonfarm activities is influenced by individual or household specific factors, as well as other social, economic and environmental factors. Various social relations, institutions, organizations, policies, as well as trends, shocks and seasonality modify access to and ability to convert livelihood assets into livelihood outcomes

Theoretical analysis of household income revealed that rural income is mainly derived from farm and nonfarm sources. Farm and non-farm variables played a vital role in rural household economy. All variables had their own effects, either increasing or decreasing effect. In this part the study tries to investigate the determinants of income to explore the basic sources of welfare of rural households. It also examined what characteristics of rural households were associated with their real income. It used econometric models and the ordinary least square (OLS) regression estimation technique to establish relationships between income and various household characteristics. It considered both economic and non-economic characteristics of rural households to identify determinants of household income (Idowu et al. 2011).

The economic characteristics include land size owned by individual households, and income shares from agriculture, wage-salary, business-commerce, gift-remittance assistance and income from other sources. The noneconomic characteristics include household size, household type, household head's age, Sex and educational status. One important dummy variable will be used to capture the effects of credit constraint on the specific household income. These variables included whether the household has credit constraints or not. This implies that a borrower household who needs a desire for more credit and non borrowers who responded that they couldn't obtain credit will assumed as credit constraint (Vedeld et al., 2012).

\section{Determinants of Agricultural Productivity and rural Household Income 3.1 Agricultural productivity and rural household income in developing Countries}

There exists quite vast literature on the trends of agricultural productivity, factors affecting agricultural productivity and ways to improve agricultural productivity in both developed and developing countries. Agricultural productivity of a given farm household is determined on many factors in the literature.

The level and dynamics of agricultural productivity affect well-being, structural transformation and development in LDCs (Gollin, 2010). The level and growth of agricultural productivity are critical both to the wellbeing of the population of the least developed countries (LDCs) and to the structural transformation of their economies. They are major determinants of poverty and of the income gap that separates them from other developing countries (ODCs) and developed countries, and play an essential role in the processes of rural structural transformation and development and in strengthening the rural non-farm economy (UNCTADF/LDC/, 2015).

It is believed that land size is an indispensable asset of agricultural production increment. According to Teryomenko (2008) the relationship between farm size and production is non-linear in a manner first it increases and then decreases (when land size exceeds the optimal amount). A finding in Rwanda by Mpawenimana (2005) reveals that land holding size is directly related with banana production; and while quantifying a $1 \%$ expansion in land size will result in $0.32 \%$ increase in agricultural output. Adebiyi and Okunlola (2013) found that those with large farm size tend to adopt cocoa farm rehabilitation techniques; diversify their crops and protect crop failures in time of erratic rainfall (Falco et al., 2010); use crop rotation and fallowing as a mechanism of soil fertility maintenance (Lugandu, 2013). Furthermore, Endrias et al. (2013) purport that those who have large farm size can expand production by exploiting economies of scale; higher input usage and tend to reject the traditional broadcasting method by adopting row-planting method which is pertinent for increasing productivity and led to employ High Yielding Varieties (HYV).

Agricultural productivity increases more in developed countries compared to less developing countries. This is due to high investment in research and development, labor, land and capital and improvement in the use of inputs such as fertilizer, machinery increases and others. It must be notice that Agricultural productivity depends primarily on technological change, improved input use efficiency and conservation of natural resources. These in 
turn, depend crucially upon investments in agricultural research, extension and human capital (Tessema, 2015).

Agricultural growth may reduce poverty through direct effects on farm productivity, incomes, and employment. It may also generate indirect impacts on the welfare of rural households through the growth linkage with the non-farm sector as well as through its impacts on food prices. There have been arguments that the poor typically spend a high share of their income on staple food; therefore, they benefit from a decline in the price of staple food induced by agricultural productivity improvement (Popli, 2010).

The determinants of rural income in Tanzania by using feasible generalized least square (FGLS) estimation technique, finds that as the size of family labor force, cultivated land size for farm income and educational level of the household head increases, the per capital income of the rural household is significantly increased (Aikaeli, 2010).

A study conducted by Akram, et al (2011) on an empirical analysis of rural household income in Pakistan by using cross-sectional data, finds that, the increase of land holding size, the level of household head education, the household's rental income and non-farm occupation are significantly increases the rural household incomes.

\subsection{Agricultural productivity and rural household income in Ethiopia}

It is important to identify factors that influence agricultural productivity in Ethiopian agriculture because these factors would automatically have indirect impacts on the poverty incidence if the force of agricultural productivity to the household income is significant. The determinants of agricultural productivity in particular country are different and distinctive from others. This section would refer to some studies in indicating of determinants of agricultural productivity rural household income in Ethiopia.

According to study conducted by Tessema (2015) on the determinants of agricultural productivity and rural households in Ethiopia, Land-labor ratio, use of fertilizer, use of pesticide, manure and household size are found to be the most significant variables that affect agricultural labor and land productivity. However, drought has statistically significant and has negative effect on both labor and land productivity by the same magnitude. Labor productivity, non-farm income and land productivity are found to be the most determinants of household income. However, number of dependency ratio is significantly and negatively affecting the rural household income. Sex of the household head is the main socio-economic factor for the variation of income among the rural households. The study also concludes that, Labor productivity is the most potent for factor of production and rural household income enhancement. The policy implication of the study is that, increasing land-labor ratio is important for agricultural productivity enhancement and promotion of both farm labor and non-farm income are best focusing to speed up for the enhancement of rural household income.

In Ethiopia, Shumet (2011) found that soil fertility is the one that best describes agricultural production and technical efficiency of farmers where those with fertile land are endowed with ample agricultural production.

Rios et al., (2008) founds that as a resource factor, livestock ownership might affect crop production positively and negatively. In Ethiopia inferred that, since crop production is expected to be supplemented by animal production; livestock endowment has dual influence on crop production in such a way that HHs who possesses a number of livestock could give all their time for livestock production where crop production will be compromised; and could also purchase agricultural inputs thereby become productive; use of animal traction, and use of manure that complements fertilizer use and enhances production; pack animals could result in ample production by transporting manure from home to the farm land without any cost.

According to a study conducted by Geta et al., (2013) by using a cross-sectional data, in walaita and Gamo Gofa zones of South nation, nationalities and people of Ethiopia for assessing productivity and technical efficiency of smallholder farmers, shows that, there was significant level of productivity improvement among maize producing farmers. They were used a two-stage estimation technique, trans log production function to determine the levels of productivity and Tobit regression model to identify factors influencing technical efficiency. The model result depicted that productivity of maize was significantly influenced by the use of labor, fertilizer, and oxen power.

Another study made by Endale, (2011) by using panel data of cereal crops and trans log estimation technique followed by FGLS for the fixed effect estimation, founds that the land size and family labors are significant for agricultural productivity in the study area of four regional state of Ethiopia.

Similarly, the study made by Gebru and Holden (2013), for the aim of investigating productivity difference among land certificate owner and non-owner in Tigray Regional state of Ethiopia by

using DEA based on malmquist productivity index, founds that on aggregate farmers those who are not owned the land certificate are less productive than those who are already owned the land certificate. The study also found no evidence to suggest that, the agricultural productivity difference between the two groups is due to difference in technical efficiency.

Another study made by Yishak (2016) for Rural farm households' income diversification in Wolaita Sodo zone implies that a significant number of rural households engage in diverse income generating activities away from purely crop and livestock production. According to the study, it is increasingly becoming clear that the 
agricultural sector alone cannot be relied upon as the main activity for rural households as a means of improving livelihood, achieving food security and reducing poverty in the study area. Income diversification is gaining prominent role in rural households' income and food security. Even though, regarding the rural economy in Ethiopia, policy makers give more attention to agricultural sector. Nevertheless, there is growing evidence that the rural sector is much more than just farming.

According to research conducted by Bihon (2015) in northern Tigria the farm income model result showed that landholding size, possession of oxen, amount of fertilizer, improved seeds, irrigation, soil quality, village distance to the district market, average distance of plots from the homestead and crop rotation were determinant variables. Farmers were engaged in off-farm activities to fulfill the cash requirements in credit constrained conditions. The laws of the region do not allow farmers to be out of their localities for more than two years and the farmers were restricted to renting out only half of their land. This discouraged farmers from off-farm participation for fear of land confiscation. In the Probit model, the determinant variables of off-farm participation were: irrigation, age, amount of money borrowed, village distance to the wereda market, fear of land confiscation and access to electricity. It is recommended that if farmers are to use chemical fertilizers, they should be supplied with High Yielding Varieties (HYV)and enough water through access to irrigation. Furthermore, farmers should be allowed to have long term off-farm employment to augment the farming sector.

In their research in Tigray and Amhara regions of Ethiopian highlands, Benin et al. (2003) found that, HYV are considered as complimentary for indigenous seeds. This is due largely to the in hospitability of the physical environment and poor market infrastructure network. In line with the HYV, as a production shifter, row planting method is found to be significant for increasing crop production. Row planting need to be backed by integrated soil fertility management practices and use of hybrid seeds that further accelerates the yield potential of the land under cultivation. Besides intercropping also called companion planting is one mechanism to save space via growing different crops at the same time with the assumption that crops can grow well together and yield will increase.

According to study conducted by Berihun Kassa (2014) in southern Tigray Besides, farm income was found to be determined significantly by age, family size, land size, plot distance, plot slope, fertilizer use, row spacing, credit access and membership to an association; where age and steep plot slope carried negative sign. Farm households do participate in off-farm activities as an alternative for dwindling farm income and small arable land size; where their crop yield was far lower than non-participants. Their probability of participation was significantly determined by gender, age, education, family size, TLU, draft animals, location and amount of credit taken; where age, TLU and location dummies hold negative sign. Transportation facilities, selling soon after harvest due to inventory credit problem; and producing non-marketable products were among the main determinants of agricultural marketing. It is therefore, recommended that, irrigation water need to be availed, contractual agreement to show productivity of HYV need to be facilitated, fertilizer should be employed on the basis of soil information, collective financing of EWs need to be introduced; inventory credit should be given; and farmers need to be trained on most effective non-farm activities.

Study conducted by Yezihalem (ND). for critical factors hampering agricultural productivity in the case of northern Ethiopia founds that, poor agricultural policy, landlessness, land fragmentation environmental degradation, population pressure, drought, famine, war and political crises have all been responsible for Ethiopian poverty and backwardness. In addition, low socioeconomic status, poor weather conditions, lack of basic infrastructures for intensive land use, different policies, land, cultural, and religious factors have undermined agricultural growth and reduced the labor-absorption potential of farming in Ethiopia.

\subsection{Factors affecting agricultural productivity}

In the above literature we reviewed a literature on factors affecting agricultural productivity and rural household income. The agricultural productivity determinants are generally estimated using the Cobb-Douglas production function models and argued that, both labor and land productivity can improve agricultural productivity. Regarding household income analysis, literature shows that, rural household income is increases through agricultural labor and land productivity due to its positive effect on household income.

In Ethiopia a study related to improved agricultural productivity and household income suggest that, the size of farm land and labor productivity are significant for agricultural productivity and positively affects the household income. Therefore, this review summarizes the different factors that affects agricultural productivity and household income in Ethiopia.

\section{Education}

Research findings have indicated the importance of education in agricultural production and income. To achieve agricultural development, the investment in production techniques and technology should be supported by a comparable investment in human capital (Schultz in Bingen et al., 2003, p. 407). This is because information and knowledge are prerequisites for farmers to adopt technology, access input, change ways of doing things and market their produce (Chowa, Garforth, \& Cardey, 2012, p. 8). 
Formal education enhances farmers' engagement in environmental programs and methods for the sustainability of agriculture (Burton, 2013, p. 22). Education is also believed to stimulate economic growth by enhancing the productive capability of farmers as well as eliminating the customs that are contrary to growth such as traditional word-of mouth communication methods (Asfaw, \& Admassie, 2004, p. 216). If there is inequality in educational endowments, the returns from irrigation are likely to remain low for poor farmers, thereby supporting the notion that "knowledge poor will remain income poor" (Hussain, \& Hanjra, 2004, p. 8). There is agreement that the accumulation of knowledge through education is an important factor for economic development (Asfaw, \& Admassie, 2004, p. 216).

\section{Gender}

Studies have also indicated that women farmers are more environmentally conscious compared to men farmers (Burton, 2013, p. 22). In the survey conducted in the four major regions of Ethiopia (Tigray, Amhara, Oromia and SNNP), Ragasa, Berhane, Tadesse and Taffesse (2013, p. 466) established that, if other influencing factors were constant, there was no productivity difference between plots possessed by female and male farmers. They further stated that it is the differences in access to quality extension services, access to inputs and the quality of the plot that created differences in productivity. In Ethiopia, gender differences in economic production remain a challenge with the majority of women still facing discrimination. However, the revised Family Law of Ethiopia has improved the rights of women to manage common marital property along with their husbands (Hallward Driemeier, \& Gajigo, 2013, p. 4).

\section{Age, family size, landholding size}

Agricultural production is influenced by other household characteristics such as the farm operator's age, family size and landholding size. The age of the household head is a proxy variable for the farming experience of farm operators. Experienced farmers are expected to enhance the productivity of their holdings. Farmers are highly dependent on their previous knowledge of farm practices in cultivating different crops (Adomi, Ogbomo, \& Inoni, 2003, p. 390).

Land is the most critical natural resource for countries like Ethiopia where the agricultural sector is the engine of the national economy (Amsalu, Stroosnijder, \& de Graaff, 2006, p. 448). Farm operators with larger landholding sizes would have a better farm income if sufficient family labour was available. This leads to an increased demand for children who can work on the land. It is not possible to expand the landholding size without matching it with an increase in the size of the household. Hence, households with larger families face a challenge to feed each of the family members and this will have its own negative effect on the nutritional status of the family (Olayemi, 2012, p. 137).

\section{Possession of oxen}

Historically, for thousands of years, oxen have been recognized as the first draft animals to serve human beings, to cultivate land and pull heavy loads (Bryant, 2010, p. 360). The possession of oxen determines the farming ability of farm operators because if farmers do not have oxen they would be obliged to rent out their land to other farmers (Holden et al., 2004, p. 375). In this case, farmers would enter into sharecropping. This further diminishes the production and income of the household as the yield is shared with oxen owners. There are advantages associated with owning oxen. Oxen owners can cultivate and sow their land at the right time. This has a positive impact on the productivity of land. In addition, oxen could also be rented out on a daily payment basis to till the land for other households. Therefore, they may serve as a source of additional income for the owners.

\section{Chemical Fertilizer, Use of manure and Pesticide}

A soil which has a high production potential and which at the same time is fertile can naturally produce high yields. Binam et al. (2004) found that farmers who are located in more fertile regions perform significantly better than those located in less fertile regions.

There is a significant of Agricultural productivity difference between chemical fertilize user household and non-user. Therefore, fertilizer appears to be the most important factor of production. Using manure is also important variables for the rural household agricultural productivity enhancement. This mean that, animal dung is very important as the chemical fertilizer may not affordable for some poor rural farm households. The agricultural productivity of the household those who are the user of pesticide and do not user vary due to use of pesticide input. Therefore, accessing and advising the rural household to the use of pesticide inputs during their farm production processes would enhance labor productivity in rural households (Tessema, 2015).

\section{Extension Service}

Extension is systems that should facilitate the access of farmers, their organizations and other market actors to knowledge, information and technologies; facilitate their interaction with partners in research, education, agribusiness, and other relevant institutions; and assist them to develop their own technical, organizational and management skills and practices. By this definition, an extension is deemed as a primary tool for making agriculture, its related activities as well as other economic activities more effective and efficient to meet the needs of the people. It is, therefore, regarded as a policy tool for promoting the safety and quality of agricultural products. Agricultural extension is aimed primarily at improving the knowledge of farmers for rural development; as such, 
it has been recognized as a critical component for technology transfer (FAO, 2010). Then Households those who were used extension service during their farm production process would increase farm productivity. Therefore, agricultural extension service delivery should be boosted through timely recruitment, periodic training of agents and provision of adequate logistics.

\subsection{Factors affecting rural household Income}

1. Land Productivity (LP): is the ratio of total household farm output per unit of area in hectare. It is also positively related with per-capita income of the rural households.

2. Agricultural Labor productivity (ALP): is the ratio of total household farm output per unit of labor (family and hired labor) input. Labor is assumed to man-day adult equivalent. It is also positively related with per-capita income of the rural households.

3. Non-farm income (NFI): it is an income that the household generate out of agricultural farm production during the agricultural production of one-year period. It includes family business, remittance and other any incomes. There has a positive relationship with the household those who have non-farm income and negative for don't have. 4. Dependency ratio: the ratio of the number of households those who are economically inactive to generate income for the households such as children less than age of 10 and the elders in the households are negatively related with household's per-capita income.

5. Tropical Live-stock units (TLUs): The number of livestock's that the households have could be valued in terms of Tropical Livestock Unit (TLU). This could be positively related with the household per-capita-income.

\section{Conclusion and Recommendation \\ 4.1.Conclusion}

This review of the literature on determinants of Agricultural productivity and rural household income in Ethiopia concludes that achieving agricultural productivity growth will not be possible without developing and disseminating improved agricultural technologies that can increase productivity to smallholder agriculture farm. It is significantly important to identify the factors that affect agricultural productivity and find the methods of the rural household income improvements.

The determinants of agricultural productivity in rural households do not much vary across labor productivity and land productivity. Land-labor ratio, use of fertilizer, use of extension service, use of pesticide, manure, number of oxen used and household size are found to be the most significant variables that affect agricultural labor and land productivity. However, drought has statistically significant and has negative effect on both labor and land productivity by the same magnitude. Labor productivity, non-farm income and land productivity are found to be the most determinants of household income. However, number of dependency ratio is significantly and negatively affecting the rural household income. Sex of the household head is the main socio-economic factor for the variation of income among the rural households.

The review also concludes that, Labor productivity is the most potent for factor of production and rural household income enhancement. Then increasing land-labor ratio is important for agricultural productivity enhancement and promotion of both farm labor and non-farm income are best focusing to speed up for the enhancement of rural household income.

\subsection{Recommendations}

This review has tried to identify the determinants of agricultural productivity and rural household incomes in Ethiopia. Based on the results obtained from the review, we suggest some policy intervention areas should be required. The policy implications that can be derived from this empirical review are:

* To increase the agricultural productivity of farm household's, by reducing the drought risk through rural environmental protection, increase land-labor ratio. The possible ways of application could be through different methods like arranging financial sources that can used for the purchase of different variable inputs and developing a work frame for non farm income employment opportunities in the rural labor market as well as shift the excessive farm labor force to the other potential cultivable area.

* To increase the rural household income, needs improvements in land-labor ratio of farmers through better allocation of financial resource.

* The combined effort is needed to design policy interventions for not only increasing labor productivity but also reducing number of dependency ratio of the household and drought risk which adversely affects labor productivity growth.

* Both agricultural labor and land productivity are important for rural household income enhancement but agricultural labor and land productivity alone does not increase rural household per capita income. Increasing the non farm income was also important for the increasing of rural household per capita income.

* Promotion of both farm labor productivity and non farm income are best focusing to speed up the enhancement of rural household per capita income. 
* It is better to strengthening the capacity of the local and federal administrative level, about the environmental protection system and rehabilitation program to protect the variations of climate over time, especially in areas adversely affected by a drought factor.

\section{References}

Adebiyi, S. and Okunlola, JO. (2013). Factors Affecting Adoption of Cocoa Farm Rehabilitation Techniques in Oyo State of Nigeria. World Journal of Agricultural Sciences 9 (3): 258-265, 2013 ISSN 1817-3047 DOI: 10.5829/idosi.wjas.2013.9.3.1736

Adomi, E.E., Ogbomo, M.O., \& Inoni, O.E. (2003). Gender factor in crop farmers' access to agricultural information in rural areas of Delta State, Nigeria. Library Review, 52, 388-393.

Aikaeli, (2010). The determinants of rural income in Tanzania.

Akram, Nazi and Ali, (2011). Empirical analysis of rural household income in Pakistan.

Alinovi, L. M. D’Errico, E. Mane and D. Romano. (2010). Livelihoods Strategies and Household resilience to Food Insecurity: An Empirical Analysis to Kenya. Paper prepared for the Conference on "Promoting Resilience through Social Protection in Sub-Saharan Africa" organized by the European Report of Development in Dakar, Senegal, 28-30 June, 2010.

Alston, J. M. Beddow, J. M. \& Pardey, P. G. (2010). Global patterns of crop yields and other partial productivity measures. In J. M. Alston, B. A. Babcock, \& P. G. Pardey, eds., The Shifting Patterns of Agricultural Production and Productivity Worldwide. Ames, Iowa: Midwest Agribusiness Trade Research and Information Center, Iowa State University.

Alston, J. M. \& Pardey, P. G. (2014). Agriculture in the global economy. Journal of Economic Perspectives 28(1), 121-146.

Amsalu, A., Stroosnijder, L., \& de Graaff, J. (2006). Long-term dynamics in land resource use and the driving forces in the Beressa watershed, highlands of Ethiopia. Journal of Environmental Management, 83, 448-459.

Anderson, C. L. Reynolds, T. \& Slakie, E. (2015). Common crop yield measures misrepresent productivity among smallholder farmers: Implications for women, sustainability and development. International Conference of Agricultural Economists Contributed Paper.

Asfaw, A., \& Admassie, A. (2004). The role of education on the adoption of chemical fertilizer under different socio-economic environments in Ethiopia. Agricultural Economics, 30, 215-228.

Asfaw, S. Shiferaw, B., Simtowe, F. \& Lipper, L. (2012). Impact of Modern Agricultural Technologies on Smallholder Welfare: Evidence from Tanzania and Ethiopia. Food policy, 37, 283-295.

Benin, S., Smale, M., Gebremedhin, B., Pender, J. and Ehui, S. (2003). The Determinants of Cereal Crop Diversity on Farms in the Ethiopian Highlands. Proceedings of the 25th International Conference of Agricultural Economists (IAAE) 16. 22 August 2003 Durban, South Africa; ISBN Number: 0-958-46098-1

Berihun Kassa (2014). Assessment of factors affecting agricultural production in the case of smaall holder farmers of southern Tigrie; northern part of Ethiopian.

Bihon Kassa (2015). factors affecting agricultural production in the case of smaall holder farmers of southern Tigrie; northern part of Ethiopian.

Birthal, P. S., Kumar, S., Negi, D. S., \& Roy, D. (2015). The impacts of information on returns from farming: evidence from a nationally representative farm survey in India. Agricultural Economics 46, 549-561.

Carletto, C. Gourlay, S. \& Winters, P. (2015a). From guesstimates to GPStimates: Land area measurement and implications for agricultural analysis. Journal of African Economies, 1-36.

Carletto, G., Jolliffe, D., \& Banerjee, R. (2015b). From tragedy to renaissance: Improving agricultural data for better policies (Policy Research Working Paper 7150). Washington, D.C.: World Bank.

Carletto, G., Savastano, S., \& Zezza, A. (2013). Fact or artifact: The impact of measurement errors on the farm size-productivity relationship. Journal of Development Economics 103, 254-261.

CSA - Central Statistical Agency (2018a), Key findings of the 2017/2018 (2010 EC) Agricultural Sample Surveys, Addis Ababa, Ethiopia.

CSA - Central Statistical Agency (2018b), Agricultural sample survey 2017/18 (2010 EC), Volume I: Report on area and production of major crops (Private peasant holdings, Meher season), Statistical Bulletin 586, Addis Ababa, Ethiopia.

CSA - Central Statistical Agency (2018c), Agricultural sample survey 2017/18 (2010 EC), Volume III: Report on farm management practices (Private peasant holdings, Meher season), Addis Ababa, Ethiopia.

Cheru, F., Cramer, C. and A. Oqubay (2019), The Oxford Handbook of the Ethiopian Economy, Oxford University Press, Oxford

Davis, B., Winters, P., Carletto, G., et al. (2010). A cross-country comparison of rural income generating activities. World Development 38(1), 48-63.

Deininger, K., Carletto, C., Savastano, S., \& Muwonge, J. (2012). Can diaries help in improving agricultural production statistics? Evidence from Uganda. Journal of Development Economics 98(1), 42-50. 
Dercon, S. and D. Gollin (2019), ‘Agriculture's changing role in Ethiopia's economic transformation', in Cheru, F., Cramer, C. and A. Oqubay (eds), The Oxford Handbook of the Ethiopian Economy, Oxford University Press, Oxford, pp. 449-467

Dias Avila, A. F., \& Evenson, R. E. (2010). Total factor productivity growth in agriculture: The role of technological capital. Handbook of Agricultural Economics 4(09), 3769-3822.

Endale, K. (2011). Fertilizer Consumption and Agricultural Productivity in Ethiopia. Working Paper 003. Ethiopia Development Research Institute, Addis Ababa.

Endrias, G., Ayalneh, B., Belay, K. and Eyasu, E. (2013). Productivity and Efficiency Analysis of Smallholder Maize Producers in Southern Ethiopia. J Hum Ecol, 41(1): 67-75 (2013)

Evenson RE and JW McKinsey Jr. (1991). Research, extension, infrastructure and

Productivity change in Indian agriculture. In: Evenson RE and CE Pray, eds. Research and Productivity in Asian Agriculture. Cornell University Press. Ithaca.

Falco, SD., Mintewab, B. and Mahmud, Y. (2010). Seeds for livelihood: Crop biodiversity and food production in Ethiopia. Ecological Economics 69 (2010) 1695-1702; Contents lists available at ScienceDirect

FAO, (2010), Ethiopia Country Brief; Retrieved from www.fao.org/countries/55528/en/ eth/.

FAO - Food and Agriculture Organization of the United Nations (2018), FAOSTAT Database, Rome, Italy, retrieved July 2018 from www.faostat.org.

Fermont, A. \& Benson, T. (2011). Estimating yield of food crops grown by smallholder farmers. Washington, D.C.: International Food Policy Research Institute.

Fuglie, K. \& Schimmelpfennig, D. (2010). Introduction to the special issue on agricultural productivity growth: A closer look at large, developing countries. Journal of Productivity Analysis 33(3), 169-172.

Gollin D (2010). Agricultural productivity and economic growth. In: Pingali PL and RE

Evenson, eds. Handbook of Agricultural Economics. Elsevier. Amsterdam: 3825-3866.

Geta, E., Bogale, A., Kassa, B. and Eyasu, E. (2013), Productivity and Efficiency Analysis of Smallholder Maize Producers in Southern Ethiopia. Journal of Hum. Ecol, 41(1): pp67-75

Ghebru, H., and Holden, S. (2013). Links between Tenure Security and Food Security: Evidence from Ethiopia. IFPRI discussion paper 1288. Washington, DC: International Food Policy Research Institute.

Hallward-Driemeier, M., \& Gajigo, O. (2013). Strengthening Economic Rights and Women's Occupational Choice: The Impact of Reforming Ethiopia's Family Law. Policy Research Working Paper 6695.

Huang, J., Wang, Y., \& Wang, J. (2015). Farmers' adaptation to extreme weather events through farm management and its impacts on the mean and risk of rice yield in China. American Journal of Agricultural Economics 97(2), 602-617.

Holden, S., Shiferaw, B., \& Pender, J. (2004). Non-farm income, household welfare, and sustainable land management in a less-favoured area in the Ethiopian highlands. Food Policy, 29, 315-392

Hussain, I., \& Hanjra, M.A. (2004). Irrigation and poverty alleviation: Review of the empirical evidence. Irrig. and Drain., 53(2004), 1-15.

Idowu, A.O., J.O.Y. Aihonsu, O.O. Olubanjo and A.M. Shittu (2011), Determinants of Income

Diversification amongst Rural farm Households in SouthWest Nigeria. Economics and Finance Review, 1(5):3143

Jerven, M. (2014). The political economy of agricultural statistics and input subsidies. Journal of Agrarian Change $14(1), 129-145$

Kaminski, J. \& Christiaensen, L. (2014). Post-harvest loss in Sub-Saharan Africa - What do farmers say? Washington, D.C.: World Bank.

Olayemi, A.O. (2012). Effects of Family Size on Household Food Security in Osun State, Nigeria. Asian Journal of Agriculture and Rural Development, 2, 136-141.

Rada, N., Wang, C., \& Qin, L. (2015). Subsidy or market reform? Rethinking China's farm consolidation strategy. Food Policy 57, 93-103.

Ragasa, C., Berhane, G., Tadesse, F., \& Taffesse, A.S. (2013). Gender Differences in Access to Extension Services and Agricultural Productivity. The Journal of Agricultural Education and Extension, 19, 437-468.

Reynolds, T., Waddington, S., Anderson, C.L., Chew, A., True, Z., \& Cullen, A. (2015). Environmental impacts and constraints associated with the production of major food crops in Sub-Saharan Africa and South Asia. Food Security 7(4), 795-822.

Rezek, J. P., Campbell, R. C., \& Rogers, K. E. (2011). Assessing total factor productivity growth in Sub-Saharan African agriculture. Journal of Agricultural Economics 62(2), 357-374.

Rios, AR., Masters, WA. and Shively, GE. (2008). Linkages between Market Participation and Productivity: Results from a Multi-Country Farm Household Sample. Prepared for presentation at the American Agricultural Economics Association Annual Meeting, Orlando, Florida, July 27-29, 2008

Sandefur, J. \& Glassman, A. (2015). The political economy of bad data: Evidence from African survey and administrative statistics. Journal of Development Studies 51(2), 116-132. 
Simonyan, J. B. \& Omolehin, R. A. (2012). Analysis of impact of Fadama II project on beneficiary farmers' income in Kaduna State: a double difference method approach. International Journal of Economics and Management Sciences 1(11), 1-8.

Shumet, A. (2011). Analysis of technical efficiency of crop producing smallholder farmers in Tigray, Ethiopia. MPRA Paper No. 40461, posted 6. August 2012 13:41 UTC Available online at http://mpra.ub.unimuenchen.de/40461/

Tessema Urgessa (2015). The determinants of agricultural productivity and rural house hold in come. Addis Ababa university

UNCTAD (2014). The Least Developed Countries Report 2014: Growth with Structural Transformation - A Post2015 Development Agenda. United Nations publication.

Sales No. E.14. II. D.7. United Nations Conference on Trade and Development. New York and Geneva.

Vedeld, P., A. Jumane, G. Wapalila and A. Songorwa. (2012). Protected areas, poverty and Conflicts: A livelihood case study of Mikumi National Park, Tanzania. Forest Policy and Economics (2012), DOI: 10.1016/j.forpol.2012.01.008

World Bank, FAO, \& UN (2010). Global Strategy to Improve Agricultural and Rural Statistics (Report No. 56719GLB). Washington, D.C.: World Bank.

World Bank (2018), World Development Indicators Data Catalog, World Bank, Data.worldbank. https://data.worldbank.org/country/ethiopia

Yezihalem Tesfa (ND). Critical factors hambering agricultural productivity in northern Ethiopia.

Yishak Gecho (2016). Rural Farm Households' Income Diversification: The Case of Wolaita Zone, Southern Ethiopia.

\section{Biographies}

My name is Sura Degefu Tadessa. I was born on 5th December of 1996 at Guliso town, in the National Regional State of Oromia, Ethiopia. I have graduated my Bachelor of Science in Agricultural Economics from Addis Ababa University on 6 July of 2017. For the last 2 years and 7 months, I have worked at the Ethiopian Institute of Agricultural Research.

At this time, I am an "Assistant researcher I" at Ethiopian institute of Agricultural Research. During my stay at work, I have acquired experience of Project Planning, Monitoring and Evaluation Research. And also accomplishing different socio-economic research, cost benefits analysis, demonstrating and popularizing new technologies to farmers. 